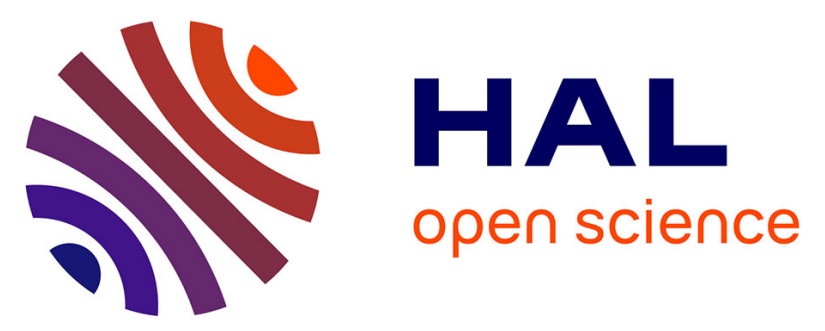

\title{
What is emerging? Understanding urbanisation dynamics in BRICS countries through a geographical approach, the case of Russia and South Africa
}

Solène Baffi, Clémentine Cottineau

\section{- To cite this version:}

Solène Baffi, Clémentine Cottineau. What is emerging? Understanding urbanisation dynamics in BRICS countries through a geographical approach, the case of Russia and South Africa. Theories and models of urbanization, pp.209-234, 2020. hal-02430052

\section{HAL Id: hal-02430052 \\ https://hal.science/hal-02430052}

Submitted on 7 Jan 2020

HAL is a multi-disciplinary open access archive for the deposit and dissemination of scientific research documents, whether they are published or not. The documents may come from teaching and research institutions in France or abroad, or from public or private research centers.
L'archive ouverte pluridisciplinaire HAL, est destinée au dépôt et à la diffusion de documents scientifiques de niveau recherche, publiés ou non, émanant des établissements d'enseignement et de recherche français ou étrangers, des laboratoires publics ou privés. 


\section{What is emerging? Understanding urbanisation dynamics in BRICS countries through a geographical approach, the case of Russia and South Africa}

Solène Baffi, Stellenbosch University, UMR Géographie-cités, solene.baffi@gmail.com Clémentine Cottineau, Université Paris 1, UCL-CASA, CNRS, c.cottineau@ucl.ac.uk

\section{Introduction}

Two nations transitioned most drastically in the 1990s. First, in 1991, Russia emerged from more than 70 years of a socialist regime (the Soviet Union). Soon after, in 1994, South Africa put an end to about 45 years of apartheid. Both countries, in doing so, embraced neoliberal economic principles alongside democracy. In the background, China was moving towards a more market-based economy, whereas India and Brazil became production and trade giants, forming a novel collection of nations put hastily together under the acronym BRICS by Goldman Sachs in 2001. This aggregation was initially to serve financial analysis purposes only, but it strokes a chord with those who had noted the increasing economic and political power that these nations gained in the 2000s. These countries themselves later embraced the idea and started meeting regularly (fig. 1).

Figure 1. The BRICS leaders in 2014.

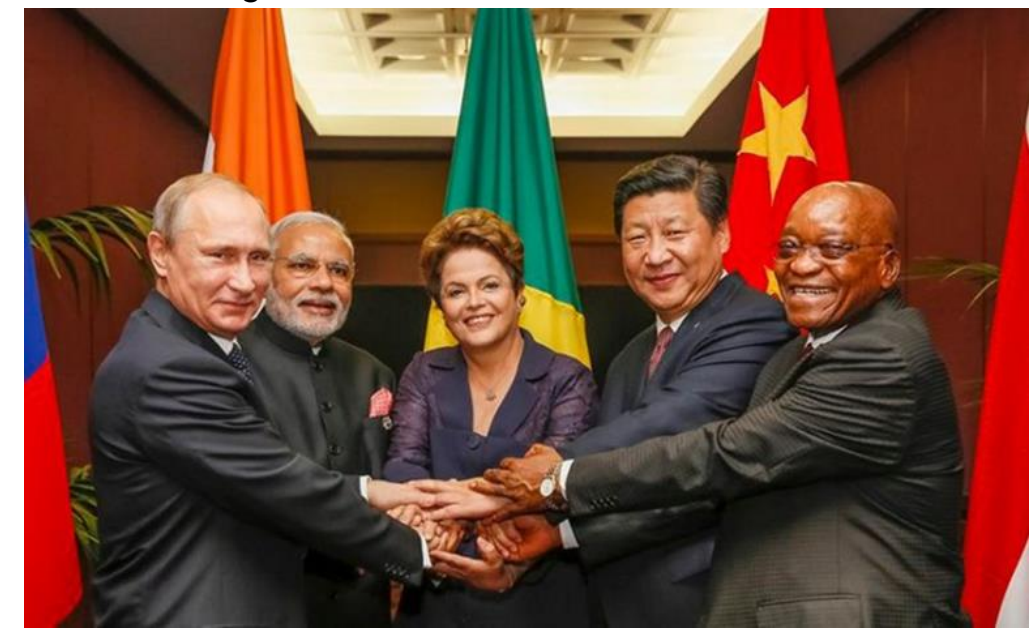

From left to right: V. Putin, N. Modi, D. Rousseff, J. Xi and J. Zuma. Photo by Roberto Stuckert Filho, Agência Brasil, Wikipedia Commons

I. Turok confirms the definition of BRICS countries as "fast-growing, middleincome, emerging powers to rival Europe and North America" (Turok, 2014, p.123), but he suggests that they also have common features regarding urbanisation. In particular, he sees in them a new historical relationship between development and urbanisation: the growth of cities without economic growth. This situation reverses the historical example of western countries' concomitant growth of urbanisation and economic development. It suggests that either the cost of rural-to-urban migrations (housing and service provision, congestion, unemployment, etc.) outpaces the usual economic 
benefits associated with the agglomeration of people, firms and capital (Duranton and Puga, 2004; Rosenthal and Strange, 2004) in BRICS countries where populations are way more numerous and cities are growing very fast, either that national economic growth has historically been the driver that fueled the growth of cities rather than the opposite, as M. Polese (2005) argues. More generally, as these countries have become the focus of new analytic light, it is legitimate to wonder if scientific models commonly used to study, to understand and to predict urbanisation dynamics are similarly rendered wrong or less useful by the recent experience of BRICS countries. If so, what is emerging instead?

In this chapter, we give a go at these questions, starting with the problematic definition of the concepts we are working with. Indeed, both emergence and models have polysemous meanings, notwithstanding urbanisation. The first section will expose two options for each concept, that we will refer to when explore their relationships. In the following sections, we present two sets of model examples: a set of models which are contested and/or falsified when applied to the urban conditions of BRICS countries, and a set of models which are corroborated and still useful. They are completed by a fourth section on "models to re-invent", in which we argue that the new urban experience in countries of the former socialist block and the Global South should not be only a terrain to test existing concepts and theories about cities but should become examples from which to start to generalise new regularities and more encompassing urban theories.

Throughout the chapter, we refer to BRICS countries but with a special focus on its most unusual members: South Africa and Russia. It has become rather consensual to admit that urban theories have to be re-worked if and when they do not help us understand emergent urbanisation in China and in India (Brazil to a lesser extent). However, the cases of Russia and South Africa in the group of BRICS seem less influential in this regard, as they can easily be pushed to the side for being "too specific" cases. Their very inclusion in the BRICS is even sometimes compromised (when South Africa is outed by the acronym BRIC, or when Russia is "forgotten" along the way, as in Turok's (2014) single-country description of urbanisation and development of BRICS countries from the Global South).

\section{Working with polysemous concepts: Emergence and models in urbanisation studies.}

Because of the use of the same words for different meanings, our research question could span over quite different fields. Some elements of definition and disentanglement below will help up clarify the analysis to come.

\subsection{Emergence}

Although the use of "emergence" is very common in scientific writing in general (on average one occurrence every three pages in our bibliography) there are two very different formalised uses of the concept that are of relevance to our subject. The first one refers to developmental economics, mostly through the expression "emergent 
economies". The second one refers to the multidisciplinary field of complexity science, where it qualifies objects ("emerging pattern", "emerging property") or is qualified itself ("strong emergence", "weak emergence").

The first use of "emergence" stems from the economic field, as the term was coined in the financial sector in the 1980's. It then described developing countries showing a rapid economic growth combined with an important local market and which offered secured investment opportunities. Nowadays, the term does not strictly refer to an economic understanding. Indeed, other common features bring together the "emerging countries", such as the completion of the demographic transition and a strong demographic growth, or the stability of their domestic political life (Gabas and Losch, 2008). However, although it is commonly used, the term "emerging" remains very seldom defined. A few geographers tried to identify the commonalities among emerging countries in order to understand to what extent the notion has an analytical meaning. Besides the intense economic growth, these countries show a transformation in their economic structure leading to more added value (often linked to industrialisation) and the apparition of a middle-class. This last point entails as well deep social transformations through the adoption of globalised standards and the production of hybrid cultural products (Erkip, 2003; Fleury and Houssay-Holszchuch, 2012). Also, emerging countries present high urbanisation rates and specific spatial configurations. In particular, the economic growth and foreign investments often lead to increased inequalities and polarization processes within urban spaces, resulting in urban fragmentation (Bret, 2011). Eventually, the geopolitical influence is another characteristic that can be attributed to emerging countries, as they happen to form a counter-power to the G7 members (Gabas and Losch, 2008) and therefore to represent the voices of "not-yet-fully-emerged" countries of the South among international organisations. In the case of Russia and South Africa, their inclusion in this group also results from their geopolitical reach, both at the regional and international level (Darbon, 2008; Jaffrelot, 2008). Some scholars question the relevance of the notion of emergence as another way of categorising non-developed countries. By definition, "emergence" indicates a momentary stage, the transition from one stage to another (Morange, 2011). While recent research underlines the necessity to grasp cities and territories of the South not from the lens of models developed in the North, but according to their own trajectory (Shatkin, 2007; Parnell \& Robinson, 2012), scholars such as Lorrain (2011) argue against using the term "emerging" in a normative way.

Regarding the second use of "emergence" in complexity science, it represents a rather central concept. Emergence is associated with the appearance of new properties and/or patterns with increasing levels of organisation and complexity for systems in which elements interact with their environment, in time and with each other (Lestienne, 2015). More critical to the definition, the emergent properties of higher-level objects can be explained by but not assigned to the lower-level elements. For example, in the model proposed by T. Schelling (1979), city-wide segregation patterns occur through the residential moves of the agents even though none of them is individually strongly intolerant to residing next to agents from a different group. In the case of systems of cities, D. Pumain (2006) considers the hierarchy of city sizes, their regular spacing and 
functional differentiation to be emergent properties of the system of individual cities. In the research agenda of complexity science, being able to reproduce the emergence of some macro-properties through the simulation of generative mechanisms implemented as rules of actions of micro-elements of a system is considered the first step (Marcchionni and Ylikosky, 2003) if not the gold standard (Epstein, 1999; Machamer et al., 2000) for causal explanation. Finally, D.J. Chalmers (2006) introduces a distinction between 'strong' and 'weak' emergence: in the strong case, the emergent phenomenon is not strictly deducible from the low-level entities in interaction, whereas in the weak case (which corresponds better to the emerging phenomena observed in social sciences), "truths concerning that phenomenon are unexpected given the principles governing the low-level domain" (ibid., p. 1). In the social science cases we are studying in this chapter, the emergence encountered is usually of the weak kind.

\subsection{Model}

Models are everywhere in science, and probably thousands of definitions already exist to describe their properties and functions in the different fields. In this chapter, we want to emphasize two broad aspects of scientific models: their representational and descriptive value on the one hand; their normative function on the other hand.

The model as a representation can be defined as an attempt to describe, in a simplified and/or abstract manner, an element of reality (the target). The representation has a purpose and can be guided by theory, which makes it possible for different models of the same elements of reality to co-exist in different forms. The model can be a mental, conceptual, numerical, graphical or physical representation. Its simplification means that only the main structure, core dynamics or organisation principle of the target reality is included in the model. In urban studies, examples of models range from the mental maps of K. Lynch (1960) to the 'rank-size rule' function attributed to G. K. Zipf (1949) to agent-based simulations. In this chapter, we will consider statistical models, network models and simulation models. They will be called contested or falsified when the regularity or theoretical relationship they represent is not observed empirically in one of our case study. They will be called useful when the observation corroborates the model.

The model as a blueprint is closer to its meaning in the art and fashion world. It corresponds to a normative idea of what the reality should be, either in an idealized way, either in the future if one follows the blueprint. In urban studies, this type of models is mostly present in architecture and urbanism ('what it should look like') or in the policy world of planning ('what we expect to see once the policy is implemented). In some cases, the inadequacy of such futuristic or normative plans with local conditions led scholars such as V. Watson to talk about "fantasy plans" and "urban utopias" (2015). By doing so, she underlines how the global visions and the aesthetics of the city promoted by consultants and developers in Africa and India are often oblivious to the reality on the ground. Also, the choice of specific models, due to the underlying norms and narratives, involves a political dimension or, at least, power relationships. In this chapter, we will consider these types of models as contested if the vision of what the reality should be differs between different urban actors or if the assumptions the 
model lies on are not met by reality. They will be called useful when they allow to bring new ideas and solutions to problems in BRICS cities.

\subsection{Urbanisation}

Following D. Pumain (2006), we identify two nested levels of urban organisation: that of cities as individual entities bounded by a physical or social landscape defined as 'urban', and that of the system they form by interacting together, which is bounded by national or macroregional boundaries. The system level and the cities level - the former emerging from the latter in a complexity science lexicon - are characterised by different attributes, scales and temporalities. They also imply two meanings for the concept of urbanisation.

At the macro-scale, urbanisation is the quantitative and qualitative shift from a settlement system where most citizens live in rural settings - where agricultural activities are dominant, the average density is low and communities are socially homogeneous - to a settlement system where most citizens live in urban settings whereby heterogenous citizens perform specialised and complementary tasks in denser built-up environments. Urbanisation in this sense is usually measured by the percentage of population living in cities, and the pace of urbanisation describes the rate of positive change in that direction. The model of the urban transition (Zelinski, 1971) formalises a typical urbanisation process as a logistic growth of the percentage of urban dwellers with time. Although the urban transition model does not allow a decrease of this percentage (only its asymptotic convergence towards a limiting maximum), decreases in the percentage urban can be observed and have been coined counter-urbanisation (Berry, 1976).

At the scale of a single city, urbanisation can be thought of as a diffusion process of urban characteristics to surrounding former rural locations through the extension of built-up area, the creation of new satellite towns, and/or the attraction of a new commuting workforce. Urbanisation in this sense has physical consequences (the construction of buildings, roads, amenities etc.) as well as social consequences (higher density and diversity of contacts, increased possibilities of economic specialisation, wider marketplaces etc.). Again, there is a myriad of models of urbanisation (concentric sprawl, satellite towns etc.) but fewer of de-urbanisation (or shrinkage), although the latter does happen (Oswalt, 2006), generally not symmetrically (Martinez-Fernandez et al., 2012). This phenomenon affects many Japanese, German (Oswalt, 2006) and Russian (Cottineau, 2016) cities, but also cities in rapidly urbanising countries such as China (with Daqing or Pingxiang (He et al., 2016) for example), due to their obsolete economic specialisation (mining) or network isolation.

In the remainder of the chapter, we exploit the polysemous character of these three concepts to question the legitimacy and usefulness of commonly used models to study, to understand and to predict urbanisation in BRICS countries, focusing on Russia and South Africa. Later on, we suggest the opportunity to develop new (decentered) models directly from the BRICS. 


\section{Example of contested models of urbanisation in emerging contexts}

As stated in introduction, some models fail at representing the process of urbanisation in emerging economies, whereas others are contested because they represent blueprints from a western background that do not apply in BRICS urban contexts. In this section, we review two of these, one at the scale of individual cities (the 'compact city' model), and the other one at the level of systems of cities (the 'Central places' model). Each time, we try to use the demonstration to extract some BRICS-specific regularities to explain the model failure and the potential for developing new models.

\subsection{The 'compact city' model}

The 'compact city' model is interesting as a case study because it functions both as a representational model to describe a high level of densities distributed in a concentrated way within cities, in contrast to sprawled cities, as well as a normative model of urban design. In the latter case, its use aims at reorganising polycentric and dispersed cities around pedestrian and public transport-friendly blocks of multiple land use (Cervero, 2002), following the examples of historical European cities and the principles of the New Urbanism (McCann and Ward, 2012), in a quest for higher sustainability (Burgess, 2002). These urban design principles were formalised in the late 1970's/early 1980's in the United States and summarised by the term Transit Oriented Development (TOD), which became, since then, a central tool for urban planning in many cities in the world. We will not question the generic weaknesses of this model ${ }^{1}$, only the cases where it is contested for reasons specific to BRICS urban conditions.

As a way of describing the distribution of density in cities, the urban compactness is looked at mostly in terms of measurement and comparison. In terms of measurement, it relates to the proximity between different urban functions (retail, residence, etc.), to the absence of gaps between urban structures, or to the distance between the observed shape of the city and the ideal-type of the circle by dividing the maximum distance between two individuals by the radius of the circle corresponding to the same area. In any case, it relies on several assumptions which are not necessarily met in BRICS countries in general, and in our case studies in particular. The first assumption is that morphological and human densities are well defined and that the residential population is quite stable between two random days of the week or between two random months of the year. This does not hold in Russia for example, because of the dacha phenomenon. The "mass of small wooden shed-like houses standing cheekby-jowl, each on its own plot of land, that encircle the country's towns [...] might be mistaken for the spontaneous suburbs of the Global South" (Nefedova and Pallot, 2013, p.91), but they are actually neither the new home of rural migrants, neither the results of suburbanisation: they are the week-end and seasonal second home of long-

1

For example, although "energy consumption is larger in a rich, motorized, sprawled, diffused and polycentric city. However, the compact city model seems to cause other problems; for instance, the degree of sprawl is negatively correlated with the number of fatalities related to transport. " (Le Néchet, 2012, §80) 
time city dwellers. Besides having provided a much needed food production safety net in the 1990's, they have a real advantage of providing a strong link between town and country for the citizens of the large Russian cities. However, in terms of density definition and measurement, they constitute a strong bias: morphologically, they are permanent, but socially, their settlement is temporary. Therefore, should the Russian cities be regarded as very compact on the basis of population density (Bertaud, 2004) or as sprawled cities with 'post-surburbia' (Goluchikov et al., 2010)?

The second assumption that compactness measures rely on is that the actual resident population is easily measurable. This is not the case in countries like China, where rural migrants tend to live in cities without being officially registered and counted in official statistics.

Finally, the analytical scope of the compact city model collides with the characteristics of peripheral areas in the cities of the global South. Indeed, these areas catalyse major changes and transformation due to their position of interface between urban and rural spaces, their specific insertion in the globalization processes, and their diversity (Chaléard et al., 2014). In South Africa for instance, peripheral areas can refer to gated communities, gigantic shopping malls, squatter camps, so as industrial areas or agricultural areas. The hybridity of the peripheries in the cities of the South is thus particularly visible in South African cities, where the process of suburbanisation is also strong. Suburban areas have a long history in this country, as they started blooming already in the aftermath of the Second World War as a simultaneous consequence of the diffusion of the car among the White population, and the enforcement of the Group Area Act, dividing each city along racial lines. Since the opening of the country to globalization and the market forces, development projects multiplied in these peripheries, for instance in the form of mega-malls or even casinos. Looking at this specific urban spaces, A. Mabin (2006) underlines that the lifestyle and standards developed in suburban places are often undermined, the idea of urbanity being strongly associated with density - and the model of the compact city. Yet, according to him, the complexity of the South African post-apartheid identity and urbanity lies exactly in the diversity existing in the peripheral areas, which, furthermore, show the strongest densification rates. Also, according to ideas articulated by E. Pieterse (2006), the challenge in post-apartheid consists mainly in (re)creating links and connections between communities. Within cities which peripheries concentrate most of the growth and very diverse communities, it is crucial not only to favour the densification of the city centre and the connections between the core and the peripheries, but also to enhance the circulation between the peripheral areas themselves.

As a policy, the 'compact city' model mixes arguments of sustainability (reducing the impact of car emissions or reducing land waste) with elements of historical contingency (for example, how European cities developed at a time of slow transportation means). This urban design model has circulated globally with success to become part of most urban governments' planning toolkit. However, its local implementation faces challenges. First, "the question of the relevance of compact city policies for developing countries also has to take account of the significant differences in the levels of urbanisation and rates of urban growth between developed and developing countries and between different world regions" (Burgess, 2002, p.11). Thus, 
despite global recipes being promoted by architects and urban design consultants (Mc Cann and Ward, 2012), the model-blueprint should to be adapted to the different paces of urbanisation (or urban shrinkage in the case of Russia for example). Second, it has to account for local regulations and building standards, which can be more complex outside of the western world. The example of the master plan of Perm in Russia is interesting in that respect (Zupan, 2015). Perm was the first city to adopt the 'compact city' model has its planning strategy in 2008. The city hired a Dutch firm to develop a long-term master plan which would implement the 'European compact city' model, although this plan would only be indicative, having no legal enforcement basis. After long debates between the firm, the local planners and the residents, the plan was rejected, partly as it does not comply with national planning rules or the land ownership distribution. Indeed, "the master plan for Perm' draws a glossy picture of a future 'clean' and 'rich' city, a development that is not mainly dependent on which principles of urban planning are used but instead requires a significant economic upturn, public investment and an appropriate appreciation of the existing urban heritage and history" (Zupan, 2015, p.48). This failed attempt shows that heritage (the Soviet land market and neighbourhood organisation into microraion in this case) cannot be simply replaced by new models just as easily, as the capitalist city rather "nestles in the socialist city" (Wagenaar, 2004, p.9) or most likely socialist and capitalist elements co-evolve in the post-socialist city (Golubchikov et al., 2013).

The Transit Oriented Development (TOD) can be considered as another version of the 'compact city' model, as it entails the densification of the urban space through a joint action on transport and housing. A few characteristics are identified in the literature to describe what TOD lies on: an efficient, integrated and reliable public transport system; a high quality public realm which prioritises non-motorised transport and ensures high accessibility of public transport infrastructures; a mix of residential, retail, commercial and community uses; medium to high-density development within comfortable walking distance of the public transport stations; and reduced amount of available parking bays for cars (Bickford and Behrens, 2015). The urban planning guidelines that constitute TOD explain why Bus Rapid Transit (BRT) often spawns TOD, in both global cities of the North and the South (Cervero, 2013). Nevertheless, the spread of these urban models questions their adaptation in local contexts, such as South African cities. Given the deeply entrenched spatial consequences of apartheid, densification is a priority in order to enhance both densification and accessibility in the post-apartheid city, where a majority of urban dwellers live far away from opportunities and resources. However, even though the principles of BRT and TOD offer appealing solutions to foster densification, the understanding regarding their implementation remains limited. Indeed, G. Bickford and R. Behrens (2015) identify the divergent interests and capacities of the multiple stakeholders involved as an obstacle to implement TOD. In particular, the use of land represents one of the main challenges: for some, the land located near the transport infrastructures should be dedicated to mixed-use and mixedincome housing, while for others the interest of land lies in its financial value for private investors and developers. Indeed, at this stage, private actors remain reluctant to invest in public transport or development lying on public transport, given its poor condition. In the context of post-apartheid cities, the use of land crystallises the contradictions inherent to the ambition to simultaneously implement redistributive and 
inclusive measures and to attract private investments and actors. On top of this main consideration, G. Bickford and R. Behrens (2015) also recall the lack of understanding of most stakeholders, and the necessity to enhance greater collaboration between practitioners to implement such a complex urban strategy.

Beyond the difficulties to adapt exogenous urban models in the cities of the BRICS, the circulation and adoption of models is meaningful and indicates the strategic and geopolitical agenda of the cities of the BRICS. For instance, the version of the BRT adopted in South Africa is clearly marketed as being inspired from the models developed in South America, in particular Bogota and Curitiba. The research of $A$. Wood (2015) unravels this narrative and enlightens the reasons underlying this choice. Indeed, using South American cities as a reference case could be questioned, since other cities in Africa and in India also implemented BRT systems, and present urban contexts closer to South African cities. The choice instead relates to the will to demonstrate the adoption of best practices by South African cities, as South American cities are considered to be innovative laboratories and cutting-edge with respect to transport planning. Beyond this ambition to assert the position of South African cities within the international hierarchy, É. Peyroux (2016) underlines how the agenda of Johannesburg evolved over the past years. Through the adoption and circulation of urban models, the goal is not so much to implement an international strategy aimed at positioning the city as a global city, but to show through partnerships an opening towards the cities of the BRICS countries and to assert Johannesburg's position as a catalyst place to develop South-South relationships.

\subsection{Optimising models of urban settlements}

At the level of systems of cities, the two most infamous models are optimising models: Zipf's law of cities' size distribution was explained by its author as following the 'principle of least effort', whereas Central Places' size and location follow the optimisation of accessibility and transport costs. This last model dates back to the ideas of J. Reynaud (1841), the formalization of W. Christaller (1933) and its extension by A. Lösch (1944). It aims to represent and explain the spatial distribution, size and functions of cities within a given region or country based on the distribution of population and a hierarchy of functions based on their frequency of need (or threshold for usage). For example, bakeries are needed every day, so there will be present in all towns and accessible within short times to everyone. Embassies on the other hand will be present only in the larger towns and serve a wider area. The optimisation is spatial (areas served by towns and cities are hexagonal) and hierarchical (hexagons for low level services are nested within the bigger hexagons of infrequent service areas). Despite its many critics (the model is a static equilibrium, its assumption of isotropy never holds, etc.), its prediction of a regular spacing of cities, and an increasing average distance between cities of similar increasing size is considered a rather good depiction of many western systems of cities (Germany, USA, France). In the case of BRICS cities, we find four reasons why it does not (and should not) provide a good description of the urban settlement. 
The Central Place theory (but it applies to Zipf's law as well) has been developed to describe systems at equilibrium, or at least at a point of urbanisation where the number and location of cities is rather stable, like in contemporary Europe. In the context of fast urbanising countries with high numbers of new towns emerging every year, it is hard to use the model adequately. The number of new towns, which is anecdotic in recent years for Europe, reaches paroxystic values in contemporary India, China (where a third of cities present in 2010 were not cities in 2000), and high percentages in South Africa (table 1). This fast pace of urbanisation in emerging countries is not consistent with a rapidly evolving nested structure of servicing areas and corresponding transport networks. The model is thus of little help to understand where urbanisation will proceed in the future.

Table 1. New towns and cities by city systems: BRICS vs. Europe

\begin{tabular}{|l|c|c|c|c|c|}
\hline $\begin{array}{l}\text { \% of new } \\
\text { cities } \\
\text { (n new cities) }\end{array}$ & 1960s & 1970s & 1980s & 1990s & 2000s \\
\hline Brazil & $8 \%(114)$ & $7 \%(112)$ & $6 \%(107)$ & $4 \%(68)$ & $4 \%(69)$ \\
\hline Russia (FSU) & $17 \%(233)$ & $14 \%(217)$ & $12 \%(227)$ & $3 \%(61)$ & $2 \%(40)$ \\
\hline India & \multicolumn{2}{|c|}{$38 \%(1307)$} & $11 \%(426)$ & $19 \%(885)$ & $9 \%(486)$ \\
\hline China & \multicolumn{2}{|c|}{$15 \%(149)$} & $2 \%(22)$ & $84 \%(5236)$ & $32 \%(2948)$ \\
\hline South Africa & $29 \%(25)$ & $24 \%(26)$ & $27 \%(39)$ & $39 \%(89)$ & $14 \%(35)$ \\
\hline Europe & $9 \%(315)$ & $6 \%(235)$ & $3 \%(114)$ & $2 \%(86)$ & $0 \%(2)$ \\
\hline
\end{tabular}

Source: From Cura et al., 2017, Annex 1-5. N.B. Cities in each system are defined as evolutive urban agglomerations over 10,000 inhabitants. FSU stands for Former Soviet Union.

Secondly, the Central Place model does not account for exogenous causes for city location (such as extractive industries around mineral ores), which play a major role in many BRICS economies. The rise and fall of the numerous mining cities of China, South African and Russia are thus unaccounted for in the model.

Thirdly, such optimising models assume free mobility flows between places, although BRICS countries have exhibited a wide spectrum of mobility restrictions over the years: on rural dwellers in China, on Blacks, Coloured and Asian citizens during the South African apartheid, on Soviet prisoners and strategic scientists, etc. Nowadays, transport inequalities within and between cities still reproduce certain patterns of selective mobility. This is particularly striking in the case of South Africa, due to the aggravated social and spatial effects of the apartheid policy, and the permanence of the mechanisms used to implement this policy. Especially, the economic system implemented during the apartheid lied on a paradoxical principle that is the employment of a cheap and numerous African manpower to maintain the economic prosperity of the White population, and the removal of this manpower away from the White city, i.e. the economic centres of cities. Within this perspective, more and more restrictive measures were implemented to limit the mobility of the African population within the city, and to the city. Within the city, the removal of the non-White population translated into the planning of the townships, located far away from the city centre. At the national level, the individuals who were denied access to the city (which was mainly depending on the possibility to justify for employment in town) were relocated in 
'homelands'. The homelands were autonomous territories located in the margins of the country. The absence of economic activities in these territories, where subsistence farming dominated, explained the dependence of the inhabitants on the main cities and employment centres (such as the mines) to obtain seasonal jobs. Thus, the South African economy dependend on the migration of an important part of the manpower. Although this migration system existed even before the apartheid, the difference comes from the evolution in the intensity and the institutionalisation of the system. Also, the removal of the African population towards the homelands impacted directly on the transport system: the geographic mobility became more extended, to the point that scholars such as A. Lemon (1982) used the term "frontier commuting" to evoke the regular moves of individuals between homelands and cities. As a consequence, the transport system, and more particularly the railways, orchestrated the regular commutes of workers from places located dozens or hundreds of kilometers away from the urban centres. By doing so, it blurred the traditional levels of urban observation, meaning the system's level and the city's level. Nowadays, in spite of the demise of the apartheid regime, social and spatial structures often linger. In the case of the mobility system, the persistence also results from the long-lasting imprint of the rail infrastructures, which are poorly adaptable.

Finally, the Central Places of Lösch and Christaller (or the cities along the ranksize distribution) are at best independent of each other, at worst duplicates. These models do not account for the interdependencies that link cities with one another. This is a problem in general for the models, but the legacies of some BRICS countries make it even more problematic. In the case of Russia for example, the legacy of strategic inter-dependence of Soviet urban centres in the production chain (Snyder, 1993) had produced a system of cities that are not duplicate of self-sufficient places, but a system of inter-dependent centres, where one city's monopoly production was dependent on another city's intermediate production (with all the bottlenecks involved). In South Africa, the geography of apartheid presents another deformation in the distribution of activities and functions between cities. Besides the removal of the population groups according to the racial hierarchy of apartheid, the functional structure of cities was to be disrupted. With the implementation of an artificial separation within cities, two - or more - commercial centres were to compete for the same demand. But in this context, the centrality is biased, as the functions located in the "white" city benefit from a hierarchical advantage and a better accessibility. Thus, the discrepancy between the "white" city and the township (or the homeland) worsened and exacerbated the dependence of the non-White populations to the white city which concentrated the offer for various types of services and activities. A. Lemon's comment (1982) illustrates this observation: "To the inconvenience of long-distance commuting is added the need to travel to "white" towns for most goods and services". Browett and Fair (1974) support this observation by showing how restrictions resulting from the apartheid policy (control of mobilities towards cities, restricted access to employment or the regulation to open business activities etc.) contradict the implicit rationality of the individual that is underlying in Christaller's theory or the principles of the market law. Finally, besides the dramatic consequences of the geography of apartheid, and its implications in terms of concentration of economic activities and excruciating mobilities, the spatial imbalance 
created conflicts with the logic of hierarchical distribution of economic functions as described by Christaller for instance.

As we have seen, despite some success in the global circulation of models, some models are not very useful to understand the emergent urbanisation patterns of BRICS countries, or only as benchmarks to evaluate the distance from which our case studies stand. This does not hold true for all kinds of models, and some approaches prove useful to study urbanisation in emergent contexts.

\section{Example of useful models of urbanisation in emerging contexts}

In this section, we review examples of models and research strategies which have been designed for generic contexts and help understand the specific urban developments of South Africa and the Former Soviet Union.

\subsection{Transport network and territories interactions in South Africa}

In the South African case study, we aimed at analysing the interaction between transport networks (especially railways) and cities, both at the urban system level and intra-urban level. However, notably because of the spatial implications of the apartheid, the South African case happened to show significant variations compared to other countries when traditional models are used to grasp this interaction. It led to the necessity to combine different models in order to assess the urbanisation process in South African in its complexity.

Generally, it is acknowledged that the urbanisation process comes with the development of transport networks, according to a mechanism of mutual adaptation (Cattan et al., 1994; Bretagnolle, 2009). In South Africa, the concomitance of urbanisation and the implementation of the railways, especially during the 19th century is particularly striking and questions the interaction existing between the rail network and the urban system. Moreover, this network shows several specificities at the international level that makes its observation worth. Indeed, it represents by far the largest network in Africa, as it counts for $40 \%$ of the total of railways on the continent. It is also one of the only railway network still used nowadays in Africa, after a massive wave of privatisation and closure of railway lines in the 1980's and 1990's. To assess the evolution of the railway network and its interaction with the urban system, a distinct database were built, as part of different research projects2. The database Harmoniecités SA counts the opening and closing year of each leg of the railway network between 1860 and 2016, and therefore enables to trace back its evolution. A second database, Gares interurbaines SA, identifies the urban railway stations for each date of the national census between 1911 and 1991.

2 The database Harmonie-cités SA was built as part of the ANR Harmonie-cités (project leader : A. Bretagnolle) and the database Gares interurbaines SA was built as part of the ERC Geodivercity (project leader: D. Pumain). 
A first analysis regards the evolution of the shape of the network, in order to compare it to other countries (Table 2).

Table 2. Characteristics of the South African railway network over the 20 th century.

\begin{tabular}{|c|c|c|c|c|c|c|c|c|}
\hline Year & 1911 & 1921 & 1936 & 1951 & 1960 & 1970 & 1980 & 1991 \\
\hline $\begin{array}{c}\text { Length of the } \\
\text { network (km) }\end{array}$ & 11376 & 14051 & 16655 & 19057 & 19179 & 19248 & 20575 & 20050 \\
\hline $\begin{array}{c}\text { Variation rate } \\
\text { of the network's } \\
\text { length (\%) }\end{array}$ & 2,13 & 1,14 & 0,9 & 0,06 & 0,03 & 0,67 & $-0,26$ \\
\hline $\begin{array}{c}\text { Connectedness } \\
\text { index } \beta 3\end{array}$ & 1,01 & 1,01 & 1,02 & 1,02 & 1,02 & 1,02 & 1,03 & 1,03 \\
\hline $\begin{array}{c}\text { Maximum } \\
\text { connectedness } \\
\text { index Y4 }\end{array}$ & 0,34 & 0,34 & 0,34 & 0,34 & 0,34 & 0,34 & 0,34 & 0,34 \\
\hline
\end{tabular}

Source: database Harmonie-cités SA (Baffi, 2016).

Regarding the pace of growth, it is visible that the network grows rapidly at the beginning of the $20_{\text {th }}$ century, and again around the 1980's. The connectedness index grows continously within the first decades, and stagnates from 1951 onwards, in spite of the growth of the network. Similar analyses led in other countries by K.J. Kansky (1963) enable to compare the South African network to other rail networks. Contrarily to most African countries, the connectedness index in South Africa is already above 1 in 1911, which indicates a rapid basic level of meshing. Nevertheless, the index almost does not change throughout the 20 th century, whereas the maximal connectedness index, $\mathrm{y}$, remains the same.

These trends are specific to the South African case study, and show the consolidation of a tree-pattern network, built with penetrating lines and few connections. The treepattern shape is commonplace in colonial countries, as Taaffe, Morrill and Gould recalled (in Hagett, 1973), and more specifically in Africa (Debrie, 2007). Indeed, most railway networks were built to connect the colonial harbours to the hinterlands so as to export raw materials. According to this model, the expansion of the network entails a second phase, characterised by the development and the multiplication of connections between cities; however it did not really happen in South Africa. This specificity relates

3 In order to calculate the connectedness index, the following formula is used : $\beta=L / V$ ( $L$ being the amount of lines that constitute the network, and $V$ the amount of vertices.

4 In order to calculate the index of maximal connectedness, the following formula is used $: \gamma=L /[3(\mathrm{~V}-$ 2)] 
to the extreme political and social laws implemented in the country from the 1950's, and the specific function allocated to the railway in the implementation of the apartheid geography. After the 1950's, most of the railway lines were built between the homelands and the mining areas, in order to maintain the mobility of a cheap manpower - i.e. the segregated populations. The growth of the network into a treepattern shape is therefore representative of the spatial principle on which lied the apartheid regime: to control the mobility of populations considered as undesirable, but also essential for the economic system (Baffi, 2016).

At the mesoscale of the city, the use of the railways as a planning tool and as a pivot in the functioning of the apartheid city also led to a specific model of urbanisation. The ambition to identifiy these specificities led several scholars to distort existing models elaborated in other contexts. R. J. Davies (1981) theorised a model of the apartheid city directly inspired from the segregation city model of the School of Chicago. At this scale, the function of the railway tracks was clearly articulated by the apartheid planners. Along physical elements such as mountains and rivers, or functional spaces such as industrial areas and graveyards, railway tracks were key elements to divide the urban space and organise the distribution of the population groups. Moreover, after the 1950's, most of the railway lines built in cities opened to connect the newly planned townships with the economic centres. From then on, the train became the transport mode of the segregated populations. Indeed, also at this scale, public transport enabled the daily commutes of the manpower living in the townships towards the employment areas; and in general to control the movement of the different population groups (Baffi, 2014). Hence, the tree-pattern shape progressively developed at the urban scale and became a key feature of the functioning of the apartheid city. It resulted in a structure called spatial mismatch. Initially, this notion was introduced by J. Kain in 1968 to assess the gap existing in U.S. cities between the localisation of the lower-income populations in the inner centre, and the localisation of low-skilled employment areas in suburban areas. C. Bénit (1998) and M. Naudé (2008) drew on this descriptive model by suggesting that the apartheid city presents an inverted spatial mismatch, the economic activities being located at the centre, whereas the labour pools are relegated to a distance, in spaces deprived from economic activities. Hence, whereas the apartheid city cannot be grapsed through traditional models, their distortion brings analytical elements to understand its structure and functioning.

This is even more obvious in the case of the post-apartheid city, where new dynamics overlaid from the 1990's onwards with the concomitant opening to the market law and the implmentation of redistributive measures. Firstly, with the lifting of the apartheid zoning, the White population moved towards suburban areas, as did economic activities. However, these new development areas are often located even further away from the townships (Turok, 2001). Secondly, some of the redistributive measures introduced after 1994 tend to reinforce the inherited spatial mismatch in the context of a globalised economy. Indeed, concomitantly to the re-opening of South Africa on the international stage, the government implemented a massive programme to provide for social housing. However, in a market-driven economy, the affordable land for such a programme was located on the periphery of cities, which often happened to be next to the existing townships. As a direct outcome, travel time and 
commuting costs are exceptionally high for South Africans. According to a survey made by the OECD in 2011, South Africa shows the longest average commuting time of all OECD members, with 56 minutes to commute to work. Already during apartheid, surveys showed that commuting costs represented on average more than $10 \%$ of households' incomes (Walters, 2013). According to I. Turok (2016), workers can spend between 20 to $35 \%$ of their income in commuting, which is way above the international standards. Also, while South African urban dwellers have a high mobility (regarding the amount of trips) compared to other urban dwellers worldwide, it does not entail an improved accessibility to basic resources. From similar observations, K. Lucas (2013) even erects accessibility and reliable public transport as a basic human right in South Africa. This last point represents a striking example of the specific definition of mobility in South African cities, and the difficulties to mobilise international indicators - but also planning guidelines and best practices - to appreciate and improve South African urban dwellers living conditions.

In conclusion, it appears that various models were necessary to analyse the interaction between transport network and urban systems in South Africa. It results on the one hand from the hybridity of the South African territory (Vacchiani-Marcuzzo, 2016), which show features common to industrialised countries but also pioneer territories as well as inequalities representative of the global South. On the other hand, the distance to the existing models enable to identify the specific function allocated to transport to implement the segregative geography of apartheid. Also, from the different examples mentioned, analytical, theoretical and descriptive models were used either to assess the specificities of the South African case, or as a combination to appreciate a complex territorial configuration.

\subsection{Combinatorial agent-based models in the Former Soviet Union}

For the case of the former Soviet Union, we found in a previous study (Cottineau et al., 2015; Pumain and Reuillon, 2017) that a type of modelling strategy which worked in understanding urbanisation patterns over the long time was the combinatorial approach or multi-modelling, where models are modular in nature and composed of different mechanisms implemented from alternative and competing theories. As a first step in this multi-modelling approach, we implemented a core agent-based model of interurban interactions based on urban scaling (of demand and supply with the urban population) and the gravity model (to estimate the potential of a pair of cities to exchange), and five alternative (or complementary) mechanisms implementing different theories of urban size differentiation:

1. a mechanism accounting for interaction benefits (Bonus) which provides cities whose interactions are numerous and diverse with some form of spillovers which translates into an economic increase controlled by a parameter $b$.

2. a mechanism accounting for situation advantages (Fixed Costs) which excludes from interactions the pairs of cities whose potential for exchange is too low, being too small and/or too far apart from one another. Indeed, a fixed cost $f$ being applied for interactions to take place, it is sometimes not profitable with regard to the amount anticipated for the exchange. 
3. a mechanism accounting for site effects (Resource) which provides cities with some extraction revenue (or debt) multiplicator $r$ if they happen to be located on natural deposits such as coal or oil.

4. a mechanism accounting for territorial effects (Redistribution) which mutualises wealth within regions and Republics through taxation at a rate $t$ of wealth and redistributes it based on the population shares of regional cities.

5. a mechanism of regional lagging effects (Urban Transition) which accounts for the initial position of regions in the urban transition and simulates the opportunity for rural migration in each city by extrapolating the urban transition on a calibrated logistic curve by region. The result is a "rural multiplier" $\mathrm{m}$ which is added to the population at the previous step of the model.

The 64 different combinations of model are calibrated systematically against empirical data (Cottineau et al., 2015) to provide insights of the "most probable" set of mechanisms to explain the observed urban evolution at yearly steps. The models, calibration results and analysis tools are provided online with the VARIUS application ${ }^{5}$. In the following, we analyse the hierarchy of explaining factors for the two time-periods of before and after the collapse of the Soviet Union.

Between 1959 and 1989 (the last census data before the transition of 1991), the single mechanism which provides the closest simulation to empirical data is the mechanism of regionally differentiated Urban transition. This indicates that rural migrations were probably the most significant driver of differences in urban growth for Soviet cities (table 2). Next, the two-mechanism model closest to empirical data contains, on top of the mechanism of regionally differentiated urban transitions, the mechanism of bonified exchanges (Bonus), with a lower overall distance to data. Thus, places which were at the centre of large and diversified exchanges have probably benefited most from growth. The Fixed Costs mechanism appears as the third mechanism to be added to reach a lower distance to data on a 3-mechanism model, indicating that situational characteristics had a minor but probably significant effect on Soviet urban systems. Surprisingly, Redistribution appears only as a fourth-order mechanism and reduces the distance to data only marginally. The image we have an equalising Soviet system was thus not probably translated into its urban dynamics. Finally, the urban differentiation related to Resource extraction is not a good explaining model, because as fifth mechanism in the model, it increases rather than decreases the distance to data, making the calibration worst when in the model.

Table 2. Hierarchy of explaining mechanisms in (post-)Soviet model of urbanisation.

\begin{tabular}{|l|c|c|}
\hline Best model with... & $\begin{array}{c}\text { Soviet period: 1959- } \\
\text { 1989 }\end{array}$ & Post-Soviet period: 1989-2010 \\
\hline 1 add. mechanism & Urban Transition (0.0142) & Resource (0.0052) \\
\hline 2nd add. mechanism & Bonus (0.0131) & Fixed Costs (0.0047) \\
\hline 3rd add. mechanism & Fixed Costs (0.0126) & Redistribution (0.0041) \\
\hline 4th add. mechanism & Redistribution (0.0123) & Urban Transition (0.0041) \\
\hline 5th add. mechanism & Resource (0.0131) & Bonus (0.0041) \\
\hline
\end{tabular}


Source: shiny.parisgeo.cnrs.fr/VARIUS. In parentheses: normalised distance to empirical data.

0 means that all cities' population was simulated perfectly at each census.

This hierarchy of explaining mechanisms is even more interesting when compared to the next historical period. Overall, the calibrations are better as the simulation lies closer to empirical data per year and per city, but only three mechanisms reduce this distance significantly. The first one is the Resource extraction. From last, it becomes the most important mechanism to simulate urban dynamics after the collapse of the Soviet Union. This reflects the well-known fact that post-Soviet economies are highly dependent on raw materials exportations (Garanina, 2009). The second mechanism is the Fixed Costs one, which excludes small and isolated cities from the network of urban interactions. This simulated process reflects the challenges of many shrinking cities of the far North and East which have struggled since the end of subsidies on a location and climate that was not suited for profitable (or enjoyable) living (Kontorovich, 2000; Cottineau, 2017), some of these cities having been developed through the work of prisoners and/or komsomol enthusiasts. Finally, Redistribution seems to explain to a lesser extent post-Soviet urban dynamics, but not the Urban transition or Bonus mechanisms.

All in all, we found so far that simple recipes applied to BRICS contexts do not help understanding urban dynamics of these countries, but that other modelling strategies might alleviate some of these issues. Most importantly, we think that some models need to be (re-)invented directly from the experience of BRICS urbanisation. We treat these models in the following section of the chapter.

\section{Models to (re-)invent}

Instead of trying to verify and falsify models built on the experience of western urbanisation, there is an opportunity, with emergent BRICS countries, to highlight routes for the development of new models of urbanisation, which could be useful to understand these cases and others, around demographic and social sustainability for example.

\subsection{A model for urban shrinkage}

One aspect on which urban Russia is ahead of many developed countries is that of demographic shrinkage. Depopulation - in the form of a 'second demographic transition' (Van De Kaa, 1987) - and counter-urbanisation (Berry, 1976) have been predicted for Europe and the USA, many times and long ago, but only in Russia did the level of demographic shrinkage reach a level where the majority of cities were losing population. Indeed, although the number of urban agglomerations rose from 926 in 1989 to 962 in 2002 and 981 in 2010 and the total urban population stagnated short of 100 million, the number of urban agglomerations loosing population grew after the transition to reach 500 , i.e. about $70 \%$ of the total number of agglomerations (Slepukhina, 2014; Cottineau, 2016), mostly because of a natural deficit (deaths outnumbering births) not compensated by a sufficiently positive migration balance. The challenges in terms of housing and service management in a shrinking city are 
becoming better known (Oswalt, 2006; Averkieva, 2014), but the cumulated effects over a majority of cities are still unpredicted. Similarly, the relation between the hierarchy of cities and the total urban population has only been approached through the lens of growth, around the question: are (growing) urban systems evolving towards more differentiation and city size unevenness? With the case of Russia, we have shown that a model that reproduces well the growth trajectory of cities could also simulate their shrinkage, in both the directions of a hierarchisation or a dehierarchisation (Chérel et al., 2017). Therefore, such models need to be explored in order to understand how urban shrinkage unravelled in post-transition Russia, so as to provide tools to analyse and project demographic shrinkage in other countries, such as Japan, Germany or China.

\subsection{A model for trust in urban planning for sustainable development}

A domain in which Russia, South Africa face a common challenge with respect to models of urban policies is that of trust. Indeed, in the past, the local and central governments of both countries have used urban planning and urbanisation scheme to promote an ideology harmful to large sections of the population as well as the environment. Moreover, in the period following the transition, "many Russian scholars and mayors argue that, under the current legal environment, waiting for federal grants and subsidies or getting involved in federal investment projects is much more profitable than undertaking something by yourself at the local level (Yasin, 2012; Zubarevich, 2012)" (Cottineau, Frost, 2018, p.278). As a consequence, there is a strong resistance from the population to the various attempts at planning cities as well as high expectations when planning decisions are implemented. For instance, "the refusal of the master plan in Perm' should be understood as an opportunity for the city to develop concepts based on local assets and requirements" (Zupan, 2015, p.49). If BRICS countries could come up with new models of political involvement for urban citizens, they will be able to provide useful solutions, including for the North where elections are becoming less and less of a way to express views about society, planning and cities and more of a duty ignored by many. And indeed, when policy is designed with the collective interest in mind, "it seems that carefully planned urban growth can strengthen prosperity and well-being. Finally, the BRICS experience indicates the importance of steering urban development onto a more compact and sustainable path because of the damage caused to the natural environment by negligence." (Turok, 2014, p.132)

\subsection{New models to blur the norms? Urbanisation from the South}

Several scholars recently highlighted the importance of the circulation of models developed in the global South (Verdeil, 2005) and the circulation of models between cities of the South (Peyroux, 2016). In the latter case, the circulation of the Bus Rapid Transit is a case in point, as the research of A. Wood (2015) shows. Besides the choice to develop the South African service according to the model elaborated in South American cities, the role of the paratransit within this model warrant our attention. Indeed, in Cape Town, the implementation of the BRT service, called MyCiti, started in 2011 as a way to introduce a safe and reliable transport mode as well as a tool to reform the paratransit industry (Schalekamp \& Behrens, 2013). However, in 2017 a revised version of the Integrated Transport Plan or ITP (the 12-year framework 
document presenting the guidelines of the metropolitan government regarding the transport planning) indicates a new strategy regarding the integration of the minibus. The change of approach was theorised by S. Ferro, R. Behrens and P. Wilkinson (2013) as the difference between a "de facto" hybrid transport model, such as the one developed in Curitiba, and the "de jure" model, such as the one developed in Accra. In the scenario adopted in Cape Town and Johannesburg in 2011, members of the minibus industry were given the choice either to integrate the BRT operations, or to accept a compensation in exchange for them to leave the industry. Besides the ambition to implement a safe, reliable and functional transport service, the design of the service also aimed at a complete removal of the paratransit on the BRT routes. However, seven years later, the minibus are back on the roads along the initial route, as MyCiti service cannot cope with the increasing demand6. Moreover, the design of MyCiti, inspired from Bogota's Transmilenio, turns out to be unadapted to the mobility patterns in Cape Town. The density being considerably lower in Cape Town, the feeder routes are running at a huge loss, making the whole system economically unviable. This explain why the City of Cape Town decided to move on from the "de facto" hybrid model towards the "de jure" hybrid model. It results from the assessment of the expensive costs associated to the operation of the MyCiti feeders, but it is also made possible due to the lessons learnt and the consolidation of the model used to formalised the minibus operators and the minibus associations into formalised corporations. More generally, this shift reveals how BRT can be a contested model when it implies a poor understanding of the transport industry - especially when it includes paratransit - and between the actors themselves (Schalekamp, 2017). Thus, the new version of the ITP indicates that minibus could alternatively provide feeder service without being absorbed into the MyCiti service but as a complementary service.

This revision introduces a considerable shift in the underlying planning vision. Although public policies have tried for decades to take the paratransit off the road, this new vision acknowledges the crucial role of the minibus in the functioning of a global city. This vision relates to the consideration articulated by S. Jaglin (2014) regarding the diversity of service delivery that characterises many cities in the global South. She argues that rather than an avatar of under-development, the heterogeneous ways of delivering service answer the complexity of the urbanisation process in the South. In this light, the service delivered by the minibus industry might be more appropriate to low-densities, so as the on-demand service answers better the need for flexibility. This approach contrasts with the model of the universal service historically elaborated in industrial countries and underlying most of the urban models implemented in the global South. Besides, as S. Graham and S. Marvin (2001) observed, the segmentation and diversification of service delivery happens progressively in industralised countries, where the unique offer inherent to the universal service model is less and less adapted to the social needs, economic trends and political transformation. In this perspective, one could then imagine that urban models currently developed and implemented in the

$6 \quad$ Interview made by S. Baffi with the Manager for the industry transition, Transport and Urban Development Authority, City of Cape Town (8/03/2018).

7 https://ewn.co.za/2016/05/25/MyCiti-bus-services-costs-city-R400-million 
cities of the South could be transferred to industrialised countries. For instance, the reflections conducted internationally on shared mobility, in the search of more sustainable transportation solutions, might lead to consider paratransit as a viable model.

This assumption seems to be even more accurate with the rapid diffusion of Information and Communication Technologies (ICTs) in the South. It gives rise to a reappropriation of models elaborated in North, such as on-demand transport applications based on the model developed by Uber (the example of the Go-Jek app for motorcycles in Jakarta presented by D. Lee (2018) is one of them), as well as numerous innovations in various sector (health, education, trade, governance) (Ninot \& Peyroux, 2018). Many of these innovations are developed as solutions for local challenges; however, some of them answer global issues, such as the mobile banking service M-Pesa. This service enables users to transfer money and pay with their mobile phones, even without access to a bank account. Initially created in 2007 in Kenya, this service is nowadays widespread over Africa, Asia (Afghanistan and India) and even in Eastern Europe. This example might be a harbinger that tomorrow's models might be currently forged in the South, as well as an indicator of the labile characteristics of urban norms.

\section{Conclusion}

Even if commonly used, the notion of "emerging countries" remains blurred and lacks a theoretical definition. Yet, when it refers to the BRICS countries, it designates demographic giants and most of the biggest countries in the world. Even though we do not dispute the opportunistic or descriptive use of the acronym when it was initially coined, our assumption is also that the traditional models used to assess urbanisation dynamics might not be completely relevant in such countries. Through the analyses conducted in Russia and South Africa, we identified the limits of several analytical and theoretical models to assess the main features of the urbanisation process, in particular to delineate its intensity, spatial extent and mechanisms.

However, some models turned out to be useful by pointing out the exceptional characteristics of these emerging countries, the distance to the normative framework then becoming meaningful. As theoretical exceptions or statistical residuals, the urbanisation dynamics identified in the BRICS countries even show a heuristic value, by distorting the classical understanding and the reach of models. Besides, through this study, we tried to enlighten to what extent the combination of models and levels of observation happened to be fruitful to grasp the complexity of the two countries. Indeed, in Russia and South Africa, urbanisation took place according to heterogenous processes (pioneer fronts, colonisation, authoritarian political regimes, controlled movement of populations). Also, in both cases, the existence of intertwined temporalities in the urban fabric led to use the term "post" to characterise the cities, may they be post-apartheid, or post-socialist. In the temporal sequence of the postsocialist transition, Sýkora and Bouzarovski (2012) identify urban transformations as the longest process of change, following institutional (short-term) and social (mediumterm) transformations. The prefix 'post' recalls then the necessity to deal with moments that are dead in time, but not in space (Santos, 1989, in Houssay-Holzschuch, 2010) 
by multiplying the scientific angles and scales of analysis. Thus, emerging countries require different or new sets of methodologies, in order not just to overlay models but to articulate them.

Eventually, the necessity to forge new rationalities and methodologies from the BRICS echoes the assumption formulated by G. Myers (2014) while arguing for "unexpected comparisons". Whether Russia and South Africa might be considered in many ways as specific cases, they also offer a plain analytical level to consider other territories. Therefore, we argue that it is precisely due to the complexity of the "emerging" territories, and their resistance to the normative theoretical frameworks, that they represent laboratories to understand the future trends of urbanisation, as well as creative spaces to elaborate global solutions.

\section{Bibliography}

Averkieva K. (2014), 'Shrinking cities', Opyt izoutcheniya Rossii. Ira.urban Summer School about urban reconfiguration of the post-soviet space, 20 Mai 2014, Rostovsur-le-Don (Russie).

Baffi S. (2014). Chemins de civilisation ? Le rail dans les politiques territoriales en Afrique du Sud. L'Espace géographique, 43 (4), pp. 338-355.

Baffi, S. (2016). Le chemin de fer et la ville dans les processus de territorialisation en Afrique du Sud: de la séparation à l'intégration territoriale? Doctoral dissertation, Université Paris 1-Panthéon Sorbonne.

Bénit C. (1998). Gouvernement urbain et production de la ségrégation : quelles leçons de la ville d'apartheid" ? Une comparaison Johannesburg - Los Angeles. Revue européennes des migrations internationales, 14 (1), pp. 159-192.

Berry, B.J.L., ed. (1976). Urbanization and Counter-Urbanization. Sage Publications, vol. 11, Urban affairs annual review. Beverly Hills, London.

Bertaud, A. (2004). The spatial organization of cities: Deliberate outcome or unforeseen consequence? UC Berkeley: Institute of Urban and Regional Development. Retrieved from https://escholarship.org/uc/item/5vb4w9wb

Bickford G., Behrens R. (2015). What does transit oriented development mean in a South African context? A multiple stakeholder perspective from Johannesburg. 34 th Southern African Transport Conference.

Bret B. (2011). Un questionnement géographique sur les pays émergents. Bulletin de l'Association de géographes français, 88 (3), pp. 227-240.

Bretagnolle A. (2009). Villes et réseaux de transport : des interactions dans la longue durée (France, Europe, États-Unis). Habilitation à diriger des recherches, tome 3. Université Panthéon-Sorbonne-Paris 1, $203 \mathrm{p}$.

Browett J.G., Fair T.J.D. (1974). South Africa, 1870-1970 : A View of The Spatial System. South African Geographical Journal, 56, (2), pp. 111-120.

Burgess, Rod. (2002) The compact city debate: A global perspective. Compact cities. Routledge, pp. 21-36.

Cattan N., Pumain D., Saint-Julien T., Rozenblat C. (1999). Le système des villes européennes. Paris : Economica, 193 p. 
Cervero, R., (2002). Built environments and mode choice: toward a normative framework. Transportation Research Part D , pp. 265-284.

Cervero R. (2013). Linking urban transport and land-use in developing countries. Journal of Transport and Land Use, 6 (1), pp. 7-24.

Chaléard J.-L., The Anh D., Huamantinco A., Koffi-Didia A.M., Mesclier É., Monin É., Moustier P., Ninot O. (2014). Spécificités des systèmes de productions agricoles et d'élevage à la périphérie des métropoles du Sud. Réflexions à partir de cinq cas. In Chaléard J.-L., Métropoles aux Suds, le défi des périphéries ? Paris : Karthala, pp. 225-242.

Chalmers, D. J. (2006). Strong and weak emergence. The reemergence of emergence, pp. 244-256.

Chérel, G., Cottineau, C., Reuillon, R. (2017). Using Models to Explore Possible Futures (Contingency and Complexity). In Urban Dynamics and Simulation Models, Springer : Cham, pp. 81-95.

Cottineau, C., Reuillon, R., Chapron, P., Rey-Coyrehourcq, S., Pumain, D. (2015). A modular modelling framework for hypotheses testing in the simulation of urbanisation. Systems, 3(4), pp. 348-377.

Cottineau, C. (2016). A multilevel portrait of shrinking urban Russia. Espace populations sociétés. Space populations societies, (2015/3-2016/1).

Cottineau, C., Frost, I. (2018). The Russian Urban System: Evolution Engaged with Transition. In Rozenblat C., Pumain D. and Velazquez E. (eds.) International and Transnational Perspectives on Urban Systems. Springer : Singapore, pp. 263-284.

Darbon D. (2008). Afrique du Sud : I'utilité comme ressource d'appoint d'une stratégie de puissance émergente. In Jaffrelot C. L'enjeu mondial. Les pays émergents. Paris : Les Presses de Sciences-Po., 384 p.

Davies, R.J., (1981). The spatial formation of the South African City. GeoJournal, 2 (S2), pp. 59-72.

Debrie J. (2007). Géohistoire d'un tracé technique : frontières et réseaux en Afrique de l'Ouest continentale francophone. Flux, 70 (4), pp. 49-58.

Duranton, G., Puga, D. (2004). Micro-foundations of urban agglomeration economies. In Handbook of regional and urban economics (Vol. 4, pp. 2063-2117). Elsevier.

Epstein, J. M. (1999). Agent-based computational models and generative socialscience. Complexity, 4 (5), pp. 41-60.

Erkip F. (2003). The shopping mall as an emergent public space in Turkey. Environment and Planning A., 35 (6), pp. 1073-1093.

Ferro P. S., Behrens R., Wilkinson P. (2013). Hybrid urban transport systems in developing countries: portents and prospects. Research in Transportation Economics, 39, pp. 121-132.

Fleury A., Houssay-Holzschuch M. (2012). Pour une géographie sociale des pays émergents. Echogéo, n²1

Gabas J-J., Losch B. (2008). La fabrique de l'émergence en trompe-l'oeil. In Jaffrelot C., L'enjeu mondial, les pays émergents. Paris : Les Presses de Sciences-Po., 384 p. 
Garanina O. (2009). What beyond oil and gas ? Russian trade specialisation in manufactures. Post communist Economies, 21 (1), 32p.

Golubchikov, O., Makhrova, A., Phelps, N. (2010). Post-socialist post-suburbia: growth machine and the emergence of "edge city" in the metropolitan context of Moscow. Geography, Environment, Sustainability, 3 (1), pp. 44-55.

Golubchikov, O., Badyina, A., Makhrova, A. (2014). The hybrid spatialities of transition: Capitalism, legacy and uneven urban economic restructuring. Urban Studies, 51 (4), pp. 617-633.

Graham S., Marvin S. (2001). Splintering urbanism : networked infrastructures, technological mobilities and the urban conditions. London : Routledge, $479 \mathrm{p}$.

Haggett P. (1973). L'analyse spatiale en géographie humaine. Paris : Armand Colin, $390 \mathrm{p}$.

He, S. Y., Lee, J., Zhou, T., Wu, D. (2017). Shrinking cities and resource-based economy: The economic restructuring in China's mining cities. Cities, 60, pp. 75-83.

Houssay-Holzschuch M. (2010). Crossing boundaries. Vivre ensemble dans l'Afrique du Sud post-apartheid. Habilitation à Diriger des Recherches, vol. 3, 270 p.

Jaffrelot C. (2008). L'enjeu mondial, les pays émergents. Paris: Les Presses de Sciences-Po., $384 \mathrm{p}$.

Jaglin S. (2014). Regulating service delivery in southern cities: rethinking urban heterogeneity. In Parnell S., Oldfield S. The Routledge Handbook on Cities of the Global South. London: Routledge, pp. 434-447

Kansky K. J. (1963). Structure of transportation networks : relationships between network geometry and regional characteristics. Chicago : University of Chicago, 155 p.

Kontorovich V., 2000, Can Russia resettle the Far East? Post-communist Economies, 12 (3), pp. 365-384.

Le Néchet, F. (2012). Urban spatial structure, daily mobility and energy consumption: a study of 34 european cities. Cybergeo: European Journal of Geography.

Lee D. (2018). How Ojek became Go-Jek: disruptive technologies and the infrastructure of urban citizenship in Indonesia. International Journal of Urban and Regional Research, Spotlights on Disruptive technologies

Lemon A. (1982). Migrant labour and frontier commuters : reorganising South Africa's black labour supply. In Smith D. M., Living under apartheid. London : George Allen \& Unwin, $256 \mathrm{p}$.

Lestienne, R. (2015). Dialogues sur l'émergence. Le Pommier.

Lorrain D. (2011). Métropoles XXL en pays émergents. Paris : Presses de SciencesPo, $404 \mathrm{p}$.

Lösch (1944). Die rKumliche Ordnung der Wirtschaft, Jena,

Lucas K. (2013). Making the connections between transport disadvantage and the social exclusion of low-income populations in the Tshwane Region of South Africa. Journal of Transport Geography, 19 (6), pp. 1320-1334. 
Mabin A. (2006). La suburbanisation en Afrique du Sud : entre héritage et innovation. In Lombard J., Mesclier É., Velut S., La mondialisation côté Sud. Acteurs et territoires. Paris : IRD Éditions \& ENS, $496 \mathrm{p}$.

Machamer, P., Darden, L., Craver, C. F. (2000). Thinking about mechanisms. Philosophy of science, 67 (1), pp. 1-25.

Marchionni, C., Ylikoski, P. (2013). Generative explanation and individualism in agentbased simulation. Philosophy of the Social Sciences, 43 (3), pp. 323-340.

Martinez-Fernandez, C., Audirac, I., Fol, S., Cunningham-Sabot, E. (2012). Shrinking cities: Urban challenges of globalization. International Journal of Urban and Regional Research, 36 (2), pp. 213-225.

McCann, E., Ward, K. (2010). Relationality/territoriality: Toward a conceptualization of cities in the world. Geoforum, 41 (2), pp. 175-184.

McCann, E., Ward, K. (2012). Policy assemblages, mobilities and mutations: Toward a multidisciplinary conversation. Political studies review, 10 (3), pp. 325-332

Morange M. (2011). "Émergence locale" et régénération urbaine au centre-ville du Cap. Bulletin de l'Association de Géographes Français, pp. 348-360.

Myers G. (2014). From expected to unexpected comparisons: changing the flows of ideas about cities in a postcolonial world. Singapore Journal of Tropical Geography, 35, pp. 104-118.

Naudé W. (2008). Is there a spatial mismatch in South Africa's metropolitan la bour market ? Cities, vol. 25, pp. 268-276.

Nefedova, T., Pallot, J. (2013). The Multiplicity of Second Home Development in the Russian Federation: A Case of 'Seasonal Suburbanization'? USA: Ashgate Publications, pp. 91-121.

Ninot O., Peyroux E. (2018. Révolution numérique et développement : une trajectoire singulière. Question Internationale, 90, pp. 44-52 .

Oswalt, P. (2005). Shrinking cities, volume 1: International research. Ostfildern-Ruit: Hatje Cantz.

Parnell S. Robinson J. (2012). (Re)theorizing cities from the Global South: looking beyond neoliberalism. Cities, 33 (4), pp. 593-617.

Peyroux E. (2016). Circulation des politiques urbaines et internationalisation des villes: la stratégie des relations internationales de Johannesburg. Echogéo, 36.

Pieterse E. (2006). Building with ruins and dreams : Some thoughts on realising integrated urban development in South Africa through crisis. Urban Studies, 43, pp. 285-304.

Polèse, M. (2005). Cities and national economic growth: a reappraisal. urban Studies, 42 (8), pp. 1429-1451.

Pumain, D. (2006). Hierarchy in natural and social sciences. Springer, Dordrecht.

Pumain, D., Reuillon, R. (2017). Urban dynamics and simulation models. Berlin: Springer. 
Rosenthal, S. S., Strange, W. C. (2004). Evidence on the nature and sources of agglomeration economies. In Handbook of regional and urban economics, vol. 4. Elsevier, pp. 2119-2171.

Shatkin G. (2007). Global cities of the South: emerging perspectives on growth and inequality. Cities, 24 (1), pp. 1-15.

Schalekamp H., Behrens R. (2013). Engaging the paratransit sector in Cape Town on public transport reform: progress, process and risks. Research in Transportation Economics, 39, pp. 185-190.

Schalekamp H. (2017). Lessons from building paratransit operators' capacity to be partners in Cape Town's public transport reform process. Transportation Research Part A, 104, pp. 58-66

Schelling, T. C. (1971). Dynamic models of segregation. Journal of mathematical sociology, 1 (2), pp. 143-186.

Slepukhina I., (2014), Russian cities at the crossroads: getting lost in transition or moving towards regeneration. Doctoral dissertation, Politecnico di Milano.

Snyder T., (1993), Soviet Monopoly. In Williamson J. (ed) Economic consequences of Soviet Disintegration, Washington D.C., pp. 176-243

Sýkora, L., Bouzarovski, S. (2012). Multiple transformations: Conceptualising the postcommunist urban transition. Urban Studies, 49 (1), pp. 43-60.

Turok I. (2001). Persistant polarization Post-apartheid? Progress towards urban integration in Cape Town. Urban Studies, 38 (13), pp. 2349-2377.

Turok, I. (2014). The urbanization-development nexus in the BRICS. In Parnell S., Oldfield S. The Routledge Handbook on Cities of the Global South. London: Routledge, pp. 122-138.

Turok I. (2016). South Africa's new urban agenda: Transformation or compensation? Local Economy, 31 (1-2), pp. 9-27.

Vacchiani-Marcuzzo C. (2016). L'Afrique du Sud est-elle un cas à part ? L'analyse d'une hybridité urbaine. Habilitation à Diriger des Recherches, Université Paris 1 Panthéon-Sorbonne, $190 \mathrm{p}$.

Van De Kaa D. J. (1987), Europe's Second Demographic Transition. Population Bulletin, vol. 42, pp. 1-57

Verdeil E. (2005). Expertises nomades au Sud. Eclairages sur la circulation des modèles urbains. Géocarrefour, 80 (3), pp. 165-169.

Wagenaar, C. (Ed.). (2004). Ideals in concrete: exploring Central and Eastern Europe. nai publishers.

Walters J. (2013). « Overview of public transport policy developments in South Africa ». Research in Transportation Economics, 39 (1), pp. 34-45.

Watson V. (2015). The allure of 'smart city' rhetoric, India and Africa. Dialogues in Human Geography, 5 (1), pp. 36-39.

Wilkinson P. (2006). Transit-oriented development: a strategic instrument for spatial restructuring and public transport system enhancement in South African cities? $25_{\text {th }}$ Southern African Transport Conference 
Wood A., (2015). The politics of policy circulation: unpacking the relationship between South African and South American cities in the adoption of Bus Rapid Transit. Antipode, 47 (4), pp. 1062-1079.

Zelinsky, W. (1971). The hypothesis of the mobility transition. Geographical review, pp. 219-249.

Zupan, D. (2015). Local debates on 'global' planning concepts: the 'compact European city' model in postsocialist Russia-the case of Perm'. Europa Regional, 22 (1-2), pp. 39-52. 